\title{
Analysis of Islamic Banking Market Structure in Indonesia with Panzar-Rosse Model Approach
}

\author{
Kiki Hardiansyah Siregar ${ }^{1}$, Ahmad Qarib ${ }^{1}$, Dede Ruslan² \\ ${ }^{1}$ Department of Islamic Economic, Islamic University of North Sumatera, Indonesia \\ ${ }^{2}$ Departement of Economic, State University of Medan, Indonesia \\ qq.hardiansyah017@gmail.com
}

\begin{abstract}
The purpose in this study is to determine and analyze the market structure of the Islamic banking industry in Indonesia according to the Panzar-Rosse model and the level of competition between Islamic banking industry in Indonesia. To find out the market structure of the islamic banking industry it must be analyzed the effect of EAR, NPF, BOPO, FAR, FS, $P L, P F F, P C E$ on the performance of Islamic banking as measured by ROA. The data used to answer and achieve these objectives is used secondary data from Islamic banks in Indonesia which has the largest asset ratings for a period of 6 years using the selected panel data method on the basis of Tests. The analysis model related to market structure uses the PanzarRosse model by looking for the H-statistic value and identified the Islamic banking equilibrium test on the panel data model of the performance of bank in Indonesia. This study found that the performance of Islamic banking measured by ROA simultaneously affected EAR, NPF, BOPO, FAR and FS and Panzar-Rosse approach will produce H-Stat value which is the sum of three main coefficients ofbanking inputs (labor, capital and funds). With H-Stat valued at 0.735 can be concludedthat the islamic banking industry in indonesia into the category of monopolistic market.The levels of the Islamic banking industry of Bank BNI, Bank BRI, Bank Panin and Bank Bukopin are monopolistic market while Bank Muamalat and Bank Mandiri are directed towards a joint monopoly market in the position of long-term equilibrium.
\end{abstract}

Keywords : islamic banking industry; Panzar-Rosse test, h-stat; monopolistic market.

\section{Introduction}

Has become a common understanding that the banking industry has different characteristics compared to other industries. Different from general industrial conditions, competition in the banking industry is more risky, especially in the credit and deposit market competition which can cause financial system instability. This has been empirically tested by Matutes and Vives (2000) who concluded that intense competition in the deposit market caused excessive risk by banks, even though there was a deposit guarantee mechanism. The results show a trade-off between stability and competition in the banking industry. This is indicated by the high level of banking competition in Indonesia which actually began to be felt since the openness of Indonesian banking initiated by the issuance of a policy package on 1 st June 1983 with the aim of modernizing the banking and then continued with the October package on 27th October 1988 which provided easy licenses for establishment new banks including the opening of branch offices. At that time, with funds of only Rp10 billion, investors could set up new banks, and this led to a significant increase in the number of banks.

The tradeoff between competition and stability in the Islamic banking industry can be explained theoretically through the Structure Conduct Performance(SCP).This theory believes that the market structure will affect the performance of an industry with the assumption that 
the market structure affects the behavior of company performance in the aggregate. The development of the performance of Islamic banking after 2010 is shown in Table no. 1.1.

Table 1. Performance Islamic Banking industry Period 2009 - 2013

\begin{tabular}{|c|c|c|c|c|c|}
\hline Indikator & $\mathbf{2 0 0 9}$ & $\mathbf{2 0 1 0}$ & $\mathbf{2 0 1 1}$ & $\mathbf{2 0 1 2}$ & $\mathbf{2 0 1 3}$ \\
\hline CAR & $10,77 \%$ & $16,26 \%$ & $16,63 \%$ & $14,13 \%$ & $14,44 \%$ \\
\hline ROA & $1,48 \%$ & $1,67 \%$ & $1,79 \%$ & $2,14 \%$ & $2,00 \%$ \\
\hline ROE & $25,81 \%$ & $17,58 \%$ & $15,73 \%$ & $24,06 \%$ & $17,24 \%$ \\
\hline NPF & $1,84 \%$ & $3,02 \%$ & $1,34 \%$ & $1,34 \%$ & $1,75 \%$ \\
\hline FDR & $89,70 \%$ & $89,67 \%$ & $88,94 \%$ & $100,00 \%$ & $100,32 \%$ \\
\hline BOPO & $84,39 \%$ & $80,54 \%$ & $85,63 \%$ & $82,51 \%$ & $83,40 \%$ \\
\hline
\end{tabular}

Source: Reports of Islamic Banks(2016)

The banking industry cannot be separated from the problem of market structure models such as perfect competitive market structures or imperfect competition. fair business competition values need to get more attention in the Islamic banking system and the economy in Indonesia.Enforcement of competition law is an economic instrument that is often used to ensure that competition between business actors takes place in a healthy manner and the results can be measured in the form of increasing public welfare.In business competition,the banking industry can maximize profit $(\mathrm{P}>\mathrm{MC})$ because the banking industry has a dominant market power. Relative Efficiency (RE) theory in Indonesia is in the opposite direction with the assumption of Structure Conduct Performance (SCP) which states that firm efficiency can produce high performance margins, so that in the end it can increase its market share, an imperfect banking market structure tends to potentially cause unhealthy business ventures.Thus, the market structure does not always affect performance. RE is concerned that market structures have a SCP market structure will reduce the company's efficiency.

Empirical studies related to SCP and RE for the banking industry produce varied conclusions. For the USA region, Gilbert (1984), Berger and Hanan (1998), Hannan and Liang (1993) and Hannan (1991) provide support for the SCP hypothesis. Calem and Carlino (1991) research rejects the hypothesis of SCP in the American banking industry. A slightly different result is shown in continental Europe. Goldberg and Rai (1996), Bikker and Groenveld (2000) and Punt and Van Rooij (1999) show mixed results, between the SCP and RE hypotheses.Several studies have examined banking competition in Indonesia, including Claessen and Laeven (2004) which are estimated to be competitive in 50 countries including Indonesia using the Panzar-Rosse method during the period 1994-2001. From the results of the study, the structure of the banking industry in Indonesia was classified into the category of monopolistic competition. The results of this study are also supported by Setyowati (2004) who concluded that the overall situation of Indonesian banking is monopolistic competition. Then what about the current structure of the Islamic banking market in Indonesia? Does it have a market structure of monopolistic competition? 


\section{Review of Literature}

\subsection{Basic Concept}

Measurement of competition can be divided into two parts; first, the conventional structural approach is related to the Structure Conduct Perfomance (SCP) paradigm; second, a non-structural approach, more directed at corporate behavior in influencing the market industry. There are three nonstructural approach models namely Iwata model, Bresnahan model, and Panzar-Rosse (P-R) model. In this study will be analyzed through the PanzarRosse Model.

The Panzar Rosse model testing is derived from a market model that generally determines output equilibrium by maximizing profits in the banking industry. This test is done in stages, as described below:

$R_{i}\left(X_{i}, n, Z_{i}\right)-C_{i}\left(X_{i}, W_{i}, t_{i}\right)=0$

Furthermore, at the market level (in equilibrium) there are constraint to normal profits

$R_{i}^{*}\left(X^{*}, n^{*}, z^{*}\right)-C_{i}^{*}\left(X^{*}, w, t\right)=0$

Based on these results, Panzar and Rosse define a competitive indicator called Hstatistics, which is the sum of the elasticities of reduced form revenue related to input prices:

$H=\sum_{k=1}^{m} \frac{\partial R i}{\partial W_{k i}} \frac{W k i}{R i *}$

The methodology stated by Panzar and Rosse (1987) comes from the equilibrium market model. This model depends on different pricing strategies to respond to each change in input prices, depending on competitive behavior. In other words, competition is measured to what extent the magnitude of changes in input prices is reflected in the equilibrium of corporate income.

Consider a representative bank or i. Optimization gets high profit in industry and company level. In the previous level, zero profit is a constraint that is detained.

$R_{i}\left(y_{i}^{*}, Z_{i}^{R}\right)=C_{i}\left(y_{i}^{*}, W_{i}, Z_{i}^{C}\right)$

$\mathrm{R}_{\mathrm{i}}(\cdot)$ and $\mathrm{C}_{\mathrm{i}}(\cdot)$ refers to the bank revenue and cost function $\mathrm{i}, \mathrm{y}_{\mathrm{i}} \mathrm{is}$ the output of the company, $\mathrm{W}_{\mathrm{i}}$ is the $\mathrm{K}$-vector dimension of the bank input factor (price). $\mathrm{i}, \mathrm{W} i=\left(\mathrm{W}_{\mathrm{Li}}, \ldots, \mathrm{W}_{\mathrm{Ki}}\right)$, $Z_{i}{ }^{R}$ is exogenous variable $\mathrm{J}$ vector affects the income function $Z_{i}{ }^{R}=\left(Z_{L i}{ }^{R}, \ldots, Z_{j i}{ }^{R}\right)$ and $Z_{i}{ }^{C}$ is a vector of exogenous variables $\mathrm{L}$ that shifts the cost function $Z_{i}{ }^{R}=\left(Z_{L i}{ }^{C}, \ldots, Z_{j i}{ }^{C}\right)$. At the individual level, marginal income must be equal to marginal costs.

$R_{i}^{\prime}\left(y_{i}^{*}, Z_{i}^{R}\right)=C_{i}{ }^{\prime}\left(y_{i}^{*}, W_{i}, Z_{i}^{C}\right)$

The size of the competition is formulated by the P-R model, H-Statistics, evaluating the elasticity of total income in relation to changes in input factor prices. 
$H=\sum_{K=1}^{K}\left[\frac{\partial R_{i}^{*}}{\partial W_{k i}} \cdot \frac{W_{k i}}{R_{i}^{*}}\right]$

(6)

The empirical application of the P-R approach usually assumes log-linearity in the specifications of marginal revenue and cost functions.

$$
\begin{aligned}
& \operatorname{Ln}\left(R_{i}^{\prime}\right)=a_{0}+a_{0} \operatorname{Ln}\left(y_{i}\right)+\sum_{j=1}^{j} d_{j} \operatorname{Ln}\left(Z_{j i}^{R}\right) \\
& \operatorname{Ln}\left(C_{i}^{\prime}\right)=c_{0}+c_{1} \operatorname{Ln}\left(y_{i}\right)+\sum_{K=1}^{K} b_{j} \operatorname{Ln}\left(W_{k i}\right)+\sum_{l=1}^{L} V_{j} \operatorname{Ln}\left(Z_{l i}^{C}\right)
\end{aligned}
$$

For banks that maximize profits, the output results from the equation(7):

$$
a_{0}+a_{0} \operatorname{Ln}\left(y_{i}^{*}\right)+\sum_{j=1}^{j} d_{j} \operatorname{Ln}\left(Z_{j i}{ }^{R}\right)=c_{0} c_{1} \operatorname{Ln}\left(y_{i}^{*}\right) \sum_{K=1}^{K} b_{k} \operatorname{Ln}\left(W_{k i}\right) \sum_{l=1}^{L} V_{l} \operatorname{Ln}\left(Z_{l i}^{C}\right)
$$

By rearranging the equations:

$\operatorname{Ln}\left(y_{i}^{*}\right) \frac{1}{\left(a_{1}-c_{1}\right)} \cdot\left[c_{0}-a_{0}+\sum_{K=1}^{K} b_{k} \operatorname{Ln}\left(W_{k i}\right)+\sum_{l=1}^{L} V_{l} \operatorname{Ln}\left(Z_{l i}^{C}\right) \sum_{j=1}^{j} d_{j} \operatorname{Ln}\left(Z_{j i}^{R}\right)\right]$

Reducing the form of equality of bank representative income is given by the product of bank equilibrium output $i$ and the price level in general.

$$
\operatorname{Ln}\left(R_{i}^{*}\right)=\operatorname{Ln}\left(P^{*} y_{i}^{*}\right)
$$

The price level provided with the inverse demand equation, which can also be read in the form of logarithms:

$$
\operatorname{Ln}(p)=\mu+\lambda \operatorname{Ln}(Y)
$$

Where:

$$
Y=\sum_{i=1}^{i} y_{i}
$$

Is industrial aggregate output. reducing the income equation can be obtained after using algebra.

$$
\operatorname{Ln}\left(R_{i}^{*}\right)=\alpha+\sum_{K=1}^{K} \beta_{k} \operatorname{Ln}\left(W_{k i}\right)+\sum_{Q=1}^{Q} \delta_{q} \operatorname{Ln}\left(Z_{q i}\right)
$$

$\mathrm{Z}_{i}$ is the $\mathrm{Q}$ variable bank vector, without explicit references to costs or revenue functions, $\mathrm{Z}_{i}=\left(\mathrm{Z}_{l i}, \ldots, \mathrm{Z}_{Q i}\right)$. Therefore, $\mathrm{H}$-statistics are calculated as follows:

$H=\sum_{K=1}^{K} \beta_{k}$ 
According to Panzar and Rosse, in the monopoly market, increasing input prices will increase MC (on the curve it appears that the MC curve will experience shifting), reduce output equilibrium and ultimately reduce income. So, $\mathrm{H}$ will be zero or negative. Economic intuition is that monopoly output prices are not dependent on changes in input prices. Panzar Rosse further pointed out that $\mathrm{H}$-statistics is also negative if the market structure is in the form of perfect collusive oligopoly.

The methodology stated by Panzar and Rosse (1987) comes from the aquilibrium market model. This model is very dependent on the assumption that companies will use different pricing strategies in response to changes in input factor prices, depending on market competition behavior. In other words, competition is measured by the extent to which the magnitude of changes in input prices is reflected in the equilibrium of corporate income. On the market perfect H-statistics $=1$. In this situation, a proportional increase in the price level as an input factor induces a proportional change in income without disturbing the optimal output of each company.

\subsection{The Competition Concept in Islam}

Market structure is the classification of producers into several market forms based on their characteristics, for example the type of product produced, the number of companies in an industry, the ease of entry into the industry and the role of advertising in industrial activities.

a) Perfect Competition Market

Islam emphasizes that the market must stand on the principle of free competition (perfect competition). But that does not mean that freedom is absolute, freedom must be in accordance with sharia rules. Perfect competition is a type of market with a very large number of sellers and buyers and homogeneous products sold. Prices are formed because of the market mechanism and the effects of the results of supply and demand so that sellers and buyers in the market cannot influence prices and only act as price takers.

b) Imperfect Competition Market

The imperfect competition market is the opposite of perfect competition, where the seller and the buyer are relative. Sometimes there is a market with small sellers, even just one seller. And vice versa, there are only a few buyers and only one buyer. Imperfect markets are divided into several types, namely:

1) Monopoly Market (ihtikar)

It is a form of market where there is only one seller in the market who controls the market. And a monopolist is a price maker, a monopolist can increase or decrease prices by determining the amount of goods to be produced, the fewer goods produced, the more expensive the price of goods, and vice versa.Islam, the existence of one seller on the market or who has no competitors, is not prohibited in Islam, but may not do ihtikar. Because ihtikar takes advantage of normal profits by selling a small amount of goods to get a high price.

2). Oligopoly Market

This is a market where the supply of one type of goods is controlled by several companies. the number of companies in the oligopoly market is more than two but less than ten. Oligopoly practice is usually carried out as an effort to keep companies from entering the market, and the goal of an oligopoly company is to try to enjoy profits by setting a limited 
selling price, so that there is no price competition that practices oligopoly. An oligopoly market structure is generally formed in high capital industries.

3). Monopolistic Market

Sellers in monopolistic markets are unlimited, but every product produced must have its own characteristics that distinguish it from other products. In monopolistic markets, producers have the ability to influence prices even though the effect is not as big as the monopoly or oligopoly market producers. This ability comes from the nature of the goods produced. Because of the differences and characteristics of an item, consumers will not easily move to other brands, and still choose the brand even though producers increase prices.

\section{Model Design}

The empirical data used in this study are 7 Islamic banks namely Bank Muamalat, Bank BNI Syariah, BRI Syariah Bank, Bank Syariah BCA, Bank Bukopin Syariah, and Mandiri Syariah banks which are considered to represent all Islamic banks in Indonesia for a period of 6 years from 2011- 2016. To measure competition in the banking industry, the Panzar-rosse model is used as applied by Bikker and Haaf (2002), Claessens and Laeven (2004) and Shaffer (2004). The approach taken to measure the effect of price factors on the equilibrium value is observed from total income (TR). TR is the observed income and $\mathrm{PF}, \mathrm{Pl}, \mathrm{Pk}$ is the input price. ETA and TA are bank-specific factors. H statistics are obtained by using equation specifications in the form of panel data:

$$
\begin{aligned}
& \operatorname{Ln}\left(T R_{i t}\right)=\beta_{0}+\beta_{1} \operatorname{Ln}\left(P f_{i t}\right)+\beta_{2} \operatorname{Ln}\left(P l_{i t}\right)+\beta_{3} \operatorname{Ln}\left(P k_{i t}\right) \\
& +\beta_{4} \operatorname{Ln}\left(E T A_{i t}\right)+\beta_{5} \operatorname{Ln}\left(T A_{i t}\right)+e i+\mu_{i t}
\end{aligned}
$$

An important difference between previous studies is the definition of the dependent variable that is applied to the H-Statistics estimate. Bikker and Groneveld (2000), Deltuvaite (2010) or Mkrtchyan (2005) use interest income. As an alternative, Hempell (2002), Bikker et al. (2009) apply total income or net income. In this study using total income and defining the dependent variable (TR) as the ratio of total income to total assets.Pl is the ratio of labor costs to total assets. $\mathrm{Pk}$ is the ratio of other operating costs (non-profit-sharing costs, namely taxes and amortization) to total assets, the proxy for capital costs and Pf is the ratio of profit sharing to total deposits, as a proxy for the price of loan funds. Bank-specific factors include the ratio of total equity to total assets (ETA) which is included to control differences in capital structure. Total assets (AT) are a measure of a bank that is considered capable of controlling the economic scale. The main indicator, H-statistics, is calculated as the amount of income elasticity based on input factor prices. $H=\beta 1+\beta 2+\beta 3$.

$\mathrm{H}$-Statistics is a test that must be carried out in a long-term equilibrium. this shows that a competitive capital market will equalize the rate of return adjusted for risk in the bank so that in equilibrium condition, the rate of return should not correlate with the price of input. equilibrium does not mean that competition conditions cannot change during the sample period. This is only an illustration that changes must be made in stages. previously (Molyneux et al., 1994; De Bandt \& Davies, 2000; Yu Sun, 2011; Aktan \& Masood, 2010), to test equilibrium by calculating $\mathrm{H}$-statistics $(\mathrm{H})$ and using returns as the dependent variable in the regression equation. Some literature uses regression that links returns on assets (ROA) to input prices. 
$\operatorname{Ln}\left(R O A_{i t}\right)=\beta_{0}+\beta_{1} \operatorname{Ln}\left(P f_{i t}\right)+\beta_{2} \operatorname{Ln}\left(P l_{i t}\right)+\beta_{3} \operatorname{Ln}\left(P k_{i t}\right)$

$+\beta_{4} \operatorname{Ln}\left(E T A_{i t}\right)+\beta_{5} \operatorname{Ln}\left(T A_{i t}\right)+e i+\mu_{i t}$

$E=\beta_{1}+\beta_{2}+\beta_{3}, \mathrm{H}=0$, Indicates long-term equilibrium, while $\mathrm{E}<0$ reflects disequilibrium.

Table 2 H-Statistics Interpretation

\begin{tabular}{|l|c|}
\hline \multicolumn{2}{|c|}{ Equilibrium Test } \\
\hline $\mathrm{H}=1$ & Equilibrium \\
\hline $\mathrm{H}<1$ & Disequilibrium \\
\hline \multicolumn{2}{|c|}{ Competitive Condition } \\
\hline $\mathrm{H}=0$ & Monopoly or Conjectural \\
\hline $\mathrm{H}=1$ & Short-run Olygopoly \\
\hline $0<\mathrm{H}<1$ & Perfect Competition \\
\hline \multicolumn{2}{|c|}{ Monopolistic Competition } \\
\hline
\end{tabular}

\section{Discussion}

The data used in this analysis includes 7 major Islamic banks in Indonesia for the 20112016 period. This data is collected from the annual performance of Sharia banking reports. Banking business activities based on sharia principles in 2013 increased in number with the operation of a number of new banks. The number of Sharia Business Unit was recorded not to increase from the previous year, which remained as many as 11 of Islamic Bank. while the number of Sharia Business Unit was reduced from 24 to 23. Meanwhile, the number of BPRS increased from 158 to 163 . The increase in the number of banks was also followed by the addition of office networks as shown in Table no. 1.3.

Table 3. Development of the Sharia Bank Office Network

\begin{tabular}{|l|r|r|r|r|r|}
\hline Bank Group & $\mathbf{2 0 1 1}$ & $\mathbf{2 0 1 2}$ & \multicolumn{1}{|c|}{$\mathbf{2 0 1 3}$} & $\mathbf{2 0 1 4}$ & $\mathbf{2 0 1 5}$ \\
\hline Islamic Bank & 11 & 11 & 11 & 11 & 12 \\
\hline Sharia Business Unit & 24 & 24 & 23 & 22 & 22 \\
\hline $\begin{array}{l}\text { - Total Islamic Bank } \\
\text { Office and Sharia } \\
\text { Business Unit }\end{array}$ & 1737 & 2262 & 2588 & 2483 & 2301 \\
\hline BPRS & 155 & 158 & 163 & 163 & 163 \\
\hline $\begin{array}{l}\text { - Total sharia financing } \\
\text { bank Office }\end{array}$ & 364 & 401 & 402 & 439 & 443 \\
\hline
\end{tabular}

Source: Reports of Islamic Banking (2016) 
With the increasing number of BPRS, the level of competition in Islamic banking is an interesting study and policy makers also realize that the financial sector (Islamic banking) plays an important role in the modern economy. Because this institution is an intermediary between creditors and debitors, especially Muslims. The difference in market structure that occurs will affect the level of competition in the banking industry, but specifically the Islamic banking sector, the analysis carried out must be more complex than other sectors.

In this study testing the level of competition in the Islamic banking sector in Indonesia uses equation (17) by using panel data. Meanwhile, to identify the factors that influence the level of competition in the Islamic banking market structure in Indonesia, the specification test through OLS (Fixed effect and Random effect) Based on the Hausman test obtained 16.444678 with Probability 0.0116, which concludes Random effect rejected and Fixed effect received. The panel estimation results with Fixed effect for Panzar-Rosse can be presented in table no. 1.4 .

Table 4 Estimated results of the FEM model

Dependent Variable: ROA?

Method: Pooled Least Squares

Date: 10/25/18 Time: 22:23

Sample: 20112016

Included observations: 6

Cross-sections included: 7

Total pool (balanced) observations: 42

\begin{tabular}{crrrr}
\hline \hline Variable & Coefficient & Std. Error & t-Statistic & Prob. \\
\hline \hline C & 17.18303 & 6.822140 & 2.518715 & 0.0180 \\
EAR? & 0.994886 & 0.556340 & 1.788270 & 0.0490 \\
NPF? & -0.438380 & 0.233684 & -1.875940 & 0.0399 \\
BOPO? & -9.315179 & 1.137989 & -8.185648 & 0.0000 \\
FAR? & -0.857390 & 0.458211 & -1.871170 & 0.1629 \\
FS? & 3.516086 & 1.070027 & 3.285979 & 0.0000 \\
PL? & 0.029466 & 9.329110 & 1.327310 & 0.0900 \\
PFF? & 0.661253 & 4.431799 & 2.119738 & 0.0434 \\
PCE? & 0.045308 & 0.342458 & 0.149823 & 0.8820 \\
Fixed Effects (Cross) & & & & \\
_BNI-C & 1.075530 & & & \\
_BRI-C & 0.623347 & & & \\
_PANIN_C & -0.032152 & & & \\
_MAMALAT-C & -0.438473 & & & \\
_BUKOPIN-C & -0.363080 & & & \\
BCA_C & -0.780159 & & & \\
_MANDIRI-C & -0.085013 & & & \\
\hline \hline
\end{tabular}

Effects Specification

Cross-section fixed (dummy variables)

\begin{tabular}{llll}
\hline \hline R-squared & 0.910937 & Mean dependent var & 1.019762 \\
Adjusted R-squared & 0.864756 & S.D. dependent var & 0.648877
\end{tabular}




\begin{tabular}{llll} 
S.E. of regression & 0.238628 & Akaike info criterion & 0.244631 \\
Sum squared resid & 1.537469 & Schwarz criterion & 0.865227 \\
Log likelihood & 9.862759 & Hannan-Quinn criter. & 0.472104 \\
F-statistic & 19.72543 & Durbin-Watson stat & 2.010489 \\
Prob(F-statistic) & 0.000000 & & \\
\hline
\end{tabular}

Source: results of e-views

The variables used in this model, namely Y (ROA), X1 (EAR), X2 (NPF), X3 (BOPO), $\mathrm{X} 4$ (FAR), X5 (FS), X6 (PL), X7 (PFF), X8 ( PCE). partial test is conducted to determine the significance or not significant of each regression coefficient on the dependent variable.

From 8 independent variables, there are 6 variables that affect the variables Y, EAR (X1), NPF (X2), BOPO (X3), FAR (X4), FS (X5) and PFF (X7). indicated by t-stat for the regression coefficients of each independent variable greater than t-table at level $5 \%$ with degrees of freedom 33, for variable X1 $($ EAR) t-stat $=1,788>$ t-table $(0,05 ; 33)=1,692$. Variable X2 $(\mathrm{NPF}) \mathrm{t}$-stat $=1.875>\mathrm{t}$-table $(0.05 ; 33)=1.692 . \mathrm{X} 3(\mathrm{BOPO}) \mathrm{t}$-stat $=8.187>\mathrm{t}-$ table $(0.05 ; 33)=1.692 . \mathrm{X} 4(\mathrm{FAR}) \mathrm{t}$-stat $=1.8711>\mathrm{t}$-table $(0.05 ; 33)=1.692 . \mathrm{X} 5(\mathrm{FS}) \mathrm{t}-\mathrm{stat}=$ $3.289>$ t-table $(0.05 ; 33)=1.692$ and X7 $(\mathrm{PFF}) \mathrm{t}$-stat $=2.11>\mathrm{t}$-table $(0.05 ; 33)=1.692$. While the variables X6 (PL) and X8 (PCE) have no effect on variable Y (ROA). It is shown that the $\mathrm{t}$-stat for the independent variable regression coefficients is smaller than t-table at level $5 \%$ with 33 degrees of freedom. For variable X6 (PL) t-stat $=1,327<\mathrm{t}$-table $(0.05 ; 33)=1,692$ and variable X8 $(\mathrm{PCE}) \mathrm{t}$-stat $=0.149<\mathrm{t}$-table $(0.05 ; 33)=1.692$.

Simultaneous testing involves 8 variables X1 (EAR), X2 (NPF), X3 (BOPO), X4 (FAR), X5 (FS), X6 (PL), X7 (PFF), X8 (PCE) to variable Y (ROA). ) Simultaneously using distribution $\mathrm{F}$. The results through the E-Views program obtained F-stat $=19.725>\mathrm{F}$-table $(0.05 ; 8 ; 42)=2.23$. It was concluded that X1 (EAR), X2 (NPF), X3 (BOPO), X4 (FAR), X5 (FS), X6 (PL), X7 (PFF), X8 (PCE) simultaneously had an influence on variable Y (ROA).

Through the E-Views program, it can be estimated that the adjusted $R^{2}=0.8647$ indicates that the variation of ROA can be explained simultaneously by the independent variables of $86.47 \%$ while the remaining $13.6 \%$ is explained by other factors not included in the model.

To answer the second problem, the Panzar-Rosse model is based on equation (2.14). In the PR model the three main variables used are Labor Price (PL), Financing Fund Price (PFF), and Capital Expenditures (PCE) are input factors used to obtain bank income, while the other three variables are controlling variables. Thus, each expenditure related to three variables will be calculated as input used to produce output (bank income). This research is in accordance with the output theory using Intermediation Approach, that banks not only function as producers of credit products and deposit storage services, but also function as intermediaries in channeling funds from those who have excess funds for those who lack funds. The indicators used to measure banking output are seen from the value of credit and investment channeled.

From table no. 1.4 the results obtained for the coefficient value representing the input of Price of Labor (PL) is 0.029, Price of Financing Fund (PFF) is 0.661, Price of Capital Expenditure (PCE) is 0.045 so the total number of the three input coefficients is 0.735 . This $\mathrm{H}$-stat value of 0.735 means that the level of competition in the banking sector in Indonesia is included in the market structure of monopolistic competition. 
To answer the third problem, thatthe level of competition in the banking structure in Indonesia, Panzar-Rosse calculations for each bank are carried out, the results of which are shown in the following Table no. 1.5.

Table 5. H-Statistics of Islamic Banking Industry

\begin{tabular}{|c|c|}
\hline Islamic Bank & H-Statistik \\
\hline BNI & 0,3714 \\
\hline BRI & 0,0950 \\
\hline Panin & 0,0806 \\
\hline Muamalat & $-0,0235$ \\
\hline Bukopin & 0,2259 \\
\hline BCA & $-0,2067$ \\
\hline Mandiri & $-0,1098$ \\
\hline
\end{tabular}

Source: results of e-views

Using the H-statistical model to see the overall level of competition prevailing in the market according to the P-R Model, $\mathrm{H}$-Statistics between $0<\mathrm{H}<1$. Negative $\mathrm{H}$ value arises when the competitive structure is a perfect monopoly or oligopoly. In both cases, increases in input prices are implemented as higher marginal costs, decreases in output values and then decreases in total income. If $\mathrm{H}$ is located between 0 and 1, the market structure is monopoly competition. while the H-statistic worth 1 is a perfectly competitive market structure. In this situation, the price level as an input factor induces changes in income without disturbing the optimal output of each company.

This PR model also shows the statistical value used to measure the competitiveness of an industry, its value ranges between 0 and 1 . The $\mathrm{H}$-stat value $<0$ indicates the level of competition in the banking industry is collusive competition. The $\mathrm{H}$-stat value $<1$ indicates the level of industrial competition is monopolistic competition, and the $\mathrm{H}$-stat value $=1$ which shows the level of perfect competition.

Based on Table no.5, the structure of the Islamic banking industry for BNI, BRI, Panin, and Bukopin is less than 1, this indicates that the competition level of the Islamic banking industry has a monopolistic competition market structure, while the Muamalat, BCA, and Mandiri H-stat below 0 indicates competition takes the form of collusive competition (joint monopoly).

\section{Conclusion}

From the discussion and analysis presented in the previous chapter, then the following conclusions: Equity to Total Assets Ratio (EAR) has an effect on Return on Assest (ROA), Non Performing Financing (NPF) has a negative effect on Return on Assest (ROA), Operating Income Operating Expenses (BOPO) have a negative and significant effect on Return on Assest (ROA), Financing to Assets Ratio (FAR) has no significant effect on Return on Assest (ROA), Firm Size (FS) has a positive effect and significant to Return on Assest (ROA) in Islamic banking industry companies in Indonesia. 
The Panzar-Rosse model used to measure the level of competition in the banking sector shows that Islamic banking in Indonesia in the 2011-2016 period entered into the market of monopolistic competition.

The level of competition between Islamic banking institutions in Indonesia for banks BNI, BRI, Panin, and Bukopin H-stat is less than 1, this indicates the level of competition in the Islamic banking industry is the monopolistic competition, while Muamalat, BCA, and Mandiri $\mathrm{H}$-stat below 0 indicate that the level of competition in the Islamic banking industry is collusive competition (joint monopoly).

\section{References}

Aktan, Bora \& Masood, Omar. (2010). The State of Competition of the Turkish Banking Industry: An Application of the Panzar-Rosse Model. Journal of Business Economics and Management 11 (1): 131-145.

Anonimous (2016). Laporan Pengawasan Perbankan Tahun 2016. Bank Indonesia,Jakarta.http://www.bi.go.id.

Bikker, J.A. \& Groneveld, J.M. (2000). Competition and Concentration in the EU Banking Industry. Kredit un Kapital, Volume 33: 62-98.

Bikker, J.A., \&Haaf, K.(2002). Measurement of Competition and Concentration in Banking Industry: A Review of the Literature.Economics \& Financial Modeling, Volume 9.

Bikker, J.A. Spierdijk, L \& Finnie, P. (2006). Misspecification of the Panzar-Rosse Model: Assessing Competition in the Banking Industry. DNB Working Paper No.114.

Calem, P.S. \& Carlino, G.A. (1991). The Concentration/Conduct Relationship in Bank Deposit Markets. The Review of Economics and Statistics, 73(2): 268-276.

Claessens, Stijn \& Laeven, Luc. (2004). What Drive Bank Competition? Some International Evidence. World Bank Policy Research: Working Paper 3113.

De bandt, O. \& Davis, P. (2000). Competition, Contestabality, and Market Structure in European Banking Sectors on the Eve of EMU. Journal of Banking Finance 24: 10451066.

Deltuvaite, Vilma. (2010). The Concentration-Stability Relationship in Banking System: an Empirical Research. Ekonomika IR Vadyba, 15.

Gilbert, A. (1984). Studies of Bank Market Structure and Competition: Review and Evaluation.

Goldberg, L.G. \& Rai, A. (1996). The Structure-Performance Relationship for Europian Banking. Journal of Banking anf Finance, 20 (4): 754-771.

Hannan, T.H. (1991). Foundation of the Structure-Conduct-Performance Paradigmaz in Banking. Journal if Monry, Credit and Banking, vol 23, issue 1: 68-84.

Hannan, T.H., and A. Berger. (1998). The Rigidity of Prices: Evidence from Banking Industry. American Economic Review, Volume 81.

Hannan, T.H, and Liang, J.N. (1993). Inferring Market Power from Time-Series Data. The Case of Banking Firm, in International Journal of Industrial Organization. Volume 11 issue 2, pages 205-2018.http://doi.org/10.1016/0167-7187(93)90004-V.

Hempell, H. (2002). Testing for Competition Among German Banks Discussion Paper 04/02, Economics Research Centre of the Deutsche Bundesbank.

Matutes, C., Vives, X. (2000). Imperfect Competition, Risk Taking, and Regulation in 
Banking.European Economic Review 44, Volume 1.

Mkrtchyan, A. (2005). The Evolution of Competition in Banking in a Transsition Economy: an Application of the Panzar-Rosse Model to Armenia. European Journal of Comparative Economics 2(1): 67-82.

Molyneux, P., Lloyd-Williams, D.M., Thornton, J. (1994). Competition Condition in European Banking. Journal of Banking and Finance, Volume 18.

Panzar, J.C., \& Rosse, J.N. (1987). Testing For "Monopoly" Equilibrium. Journal of Industrial Economics, Volume 35: 443-456.

Punt, L.W. \& Van Rooij, M.C.J. (1999). The Profit-Structure Relationship, Efficiency and Mergers in the European Banking industry: an Empirical Asessment. Research Memorandum WO\&E no. 604.

Setyowati, Rini. (2004). Tingkat Persaingan Industri Perbankan di Indonesia tahun 19912002. (Unpublished Master's Thesis). University of Indonesia.

Shaffer, S., 2004. A Test of Competition in Canadian Banking. Journal of Money, Credit and Banking, Volume 25.

Yu Sun, Julliana. (2011). Recent Developments in European Bank Competition. International Monetary Fund Working Paper, WP/11/146. 